\title{
REVIEWS
}

\section{Physicians' Perspectives About Burnout: a Systematic Review and Metasynthesis}

\author{
Jordan Sibeoni, MD, PhD ${ }^{1,2}$, Laura Bellon-Champel, PhD², Antoine Mousty, Msc' , \\ Emilie Manolios, Msc ${ }^{2,3}$, Laurence Verneuil, MD, PhD², and Anne Revah-Levy, \\ $M D, P h D^{1,2}$
}

\begin{abstract}
${ }^{1}$ Service Universitaire de Psychiatrie de l'Adolescent, Argenteuil Hospital Centre, Argenteuil, France; ${ }^{2}$ ECSTRRA Team, UMR-1 153, Inserm, Université de Paris, Paris, France; ${ }^{3}$ Service de Psychologie et Psychiatrie de Liaison et d'Urgences, Hôpital Européen Georges Pompidou AP-HP, Hôpitaux Universitaires Paris Ouest, Paris, France.
\end{abstract}

BACKGROUND: Doctors' burnout is a major public health issue with important harmful effects on both the healthcare system and physicians' mental health. Qualitative studies are relevant in this context, focusing as they do on the views of the physicians of how they live and understand burnout in their own professional field.

OBJECTIVE: To explore physicians' perspectives on burnout by applying a metasynthesis approach, including a systematic literature review and analysis of the qualitative studies.

DATA SOURCES: Medline, PsycINFO, EMBASE, and SSCI from the earliest available date to June 2018

REVIEW METHODS: This metasynthesis follows thematic synthesis procedures. Four databases were systematically searched for qualitative studies reporting doctors' perspectives on burnout. Article quality was assessed with the Critical Appraisal Skills Program. Thematic analysis was used to identify key themes and synthesize them. RESULTS: Thirty-three articles were included, covering data from more than 1589 medical doctors (68 residents and 1521 physicians). Two themes emerged from the analysis: (1) stress factors promoting burnout-ranked as organizational, then contextual and relational, and finally individual-factors and (2) protective factors, which were above all individual but also relational and organizational.

CONCLUSIONS: The individual and organizational levels are abundantly described in the literature, as risk factors and interventions. Our results show that doctors identify numerous organizational factors as originators of potential burnout, but envision protecting themselves individually. Relational factors, in a mediate position, should be addressed as an original axis of protection and intervention for battling doctors' burnout.

KEY WORDS: burnout; physician behavior; systematic reviews; qualitative research.

Electronic supplementary material The online version of this article (https://doi.org/10.1007/s11606-019-05062-y) contains supplementary material, which is available to authorized users.

Received October 17, 2018

Revised January 11, 2019

Accepted April 12, 2019

Published online May 30, 2019
$\mathrm{J}$ Gen Intern Med 34(8):1578-90

DOI: $10.1007 /$ s11606-019-05062-y

(C) Society of General Internal Medicine 2019

\section{INTRODUCTION}

Burnout is a work-related syndrome involving emotional exhaustion, depersonalization, and a reduced sense of personal accomplishment ${ }^{1}$. In recent years, doctors' burnout has become a major public health issue in most Western countries. Its prevalence is quite high in many countries, in residents as well as experienced physicians and regardless of the specialty ${ }^{2}$. In one recent US study, $54.4 \%$ of a cohort of 6880 physicians had experienced at least one symptom of burnout ${ }^{3}$.

Doctors' burnout has important harmful effects on the healthcare system. It appears to increase the risk of medical errors by residents ${ }^{4}$ as well as their elders ${ }^{5}$ and impair the professionalism of doctors ${ }^{6}$ as well as their productivity (availability at work, sick leaves) ${ }^{7}$. It thus costs hospitals and communities dearly ${ }^{8}$.

Consequences for doctors can also be serious, increasing their risk of suicide ${ }^{9}$, even though they are at higher risk than the general population for depression and for traffic accidents ${ }^{10}$.

The scientific literature on this subject is abundant. This quantitative literature has generated several narrative and systematic reviews as well as meta-analyses that have made it possible, in particular, to describe the correlates of doctor burnout across regions and specialties ${ }^{11}$ and its impact on their productivity $^{7}$, to list the factors, internal and external, that can cause this burnout ${ }^{12}$, and to assess the effectiveness of different interventions, focused on either the individual or the organisation ${ }^{13}$. Accordingly, young physicians, women, and those in more isolated practices appear to be at greater risk of burnout. Similarly, common personal characteristics of doctors, ones that favored their academic success, such as their perfectionism, compulsiveness, guilt, and self-denial, may predispose them to burnout, as do the current changes in healthcare environments and in hospital administration, by creating substantial external pressures ${ }^{12}$. 
To our knowledge, there is no systematic review of the qualitative literature on physician burnout. Qualitative methods are especially relevant in this context, aiming as they do to describe and understand complex phenomena in greater depth. They are a tool of choice for focusing on the views of the physicians of how they live, conceive, and understand burnout in their own professional field. Because qualitative studies are usually conducted with small samples and in specific context, there may often be concern about the generalizability of their results.

The objective of this study was to explore physicians' perspectives on burnout by applying a metasynthesis approach, including a systematic literature review and analysis of qualitative studies on the subject ${ }^{14,15}$.

\section{METHODS}

\section{Study Design}

This metasynthesis relies on our six-stage approach ${ }^{16-20}$ inspired by the model of meta-ethnography ${ }^{21}$ and the procedures of the thematic synthesis ${ }^{22}$. It complies with the ENTREQ reporting guidelines ${ }^{23}$.

Our approach consisted of six successive stages:

1. Defining the research question, the subjects, and the types of studies to be included

2. Identifying and selecting the studies

3. Assessing the quality of the studies selected

4. Analyzing the studies, identifying their themes, and translating these themes between the studies

5. Generating the themes of the analysis and structuring the synthesis

6. Writing the synthesis

The thematic analysis contained two phases: one descriptive, which defined and compared the themes, and the other interpretive, which developed original ideas drawn from the review.

\section{Search Strategy and Selection Criteria}

We conducted a systematic search in four databases according to a search algorithm specific to each base: Medline, PsycINFO, EMBASE, and SSCI through June 30, 2018. Preliminary research had identified several articles from which we selected key words. The research group used existing literature reviews to determine a list of key words, a mix of free-text terms and thesaurus terms, referring to burnout, physicians, and medical residents, and qualitative research, to collect studies indexed in the databases. Our search strategy is available as supplementary material (supplementary material online, Table S1).

Inclusion criteria were qualitative research regarding burnout from the physicians' perspective (medical doctors, residents, trainees), published in peer-reviewed journals, in English or
French language. Exclusion criteria were quantitative or mixed studies, reviews, commentaries, editorials, theses, and non-peerreviewed journal articles. We discussed potential articles at meetings of our research group, composed of specialists in qualitative research and physicians. We decided to include all studies related to physicians' burnout without requiring that it necessarily be the principal object of the study.

Extensive lateral searches - systematic checking of reference lists, hand searching of key journals and the PubMed sidebar of related articles - also sought to identify papers that might have eluded our algorithms. Three authors (AM, LBC, and JS) independently screened the papers retrieved, initially by title, then by abstract, and finally by full text.

After collecting the references and eliminating duplicates, two authors (JS and LBC) subsequently read the titles and abstracts to assess their relevance to our target subject and methodology. The database indexing of qualitative studies was rather poor, and most of the references collected were actually quantitative studies. They were eliminated at this step. When the abstract was not sufficient, we read the entire article. Disagreements were resolved during meetings of the research group. The potentially relevant articles were then read in full, and a second selection made to keep only the article that met our inclusion criteria.

\section{Assessment of Article Quality}

We assessed the quality of included articles using the Critical Appraisal Skills Program (CASP) ${ }^{24}$. It comprises 10 questions: two screening questions about the aims of the research and appropriate use of a qualitative methodology and eight questions covering research design, sampling strategy, data collection, researcher's reflexivity, ethical issues, data analysis, the findings, and the value of the research. Two authors (JS and $\mathrm{AM}$ ) performed this assessment independently and then discussed the results within the research group until we reached agreement. Given the lack of consensus about the role and function of study quality assessment as part of systematic reviews, we did not exclude any study from the analysis based on our evaluation. However, results are as reliable as they are based on the studies with high methodological quality. We therefore performed a secondary sensitivity analysis by excluding from the synthesis studies in the lowest quartile of methodological quality ${ }^{15}$.

\section{Data Analysis}

Our analysis began with an attentive reading and then repeated readings of the titles, abstracts, and texts of each article. One researcher (AM) extracted the formal characteristics of the studies, and three (JS, AM, and LBC) independently extracted and analyzed the first-order results (that is, the study results) and the second-order results (authors' interpretations and discussions of the results) in a form of a summary for each study selected; these independent analyses were then compared and discussed at the research meetings. 
Thematic analysis followed the five-stage approach (supplementary material online, Table S2). Thematic analysis made it possible to develop themes inductively, from our study data. The work of translation involved comparing and assembling the themes obtained by the analysis of each article to retain the key themes that capture similar ideas in the different articles and then to develop overarching concepts about the research question. The high level of rigor of the results was obtained by triangulation of both the data sources and the analyses: three independent analyses and monthly research meetings to discuss the results. NVivo 11 software was used to manage data, facilitate the development of themes, and verify the researchers' contribution to the findings.

\section{RESULTS}

\section{Presentation of Studies}

Of the 2807 articles initially retrieved (after duplicates were removed), 33 articles covering data from more than 1589 medical doctors (68 residents and 1521 physicians) were included in this metasynthesis (Fig. 1).

The median sample size was 22 (range, 7 to 676). These 33 studies came from 15 countries, 22 of them from English- speaking countries. Data were collected mostly through interviews (28). Table 1 describes the characteristics of the studies we included.

The quality appraisal showed that the overall quality of the studies was high (Table 2 and supplementary material online, Table S3). The principal flaw was that several papers failed to address the role of the researchers' contribution to the findings and/or interpretations. Secondary analysis without the 8 studies with the lowest quality score on CASP $(<18 / 20)$ $25,28,33,38,40,48,51,54$ did not change the results.

\section{Description of the Themes}

Two themes emerged from the analysis: (1) the stress factors promoting burnout - ranked as organizational, then contextual and relational, and finally individual - factors and (2) the protective factors, which were above all individual but also relational and organizational. Table 3 presents quotations from participants and from the authors of the primary studies for each theme. Table 4 gives a list of all the stress and protective factors found in the studies.

It is important to note that none of these studies directly explored the experience of burnout from the point of view of doctors. Several studies provided descriptive elements of doctor burnout that matched the clinical descriptions in

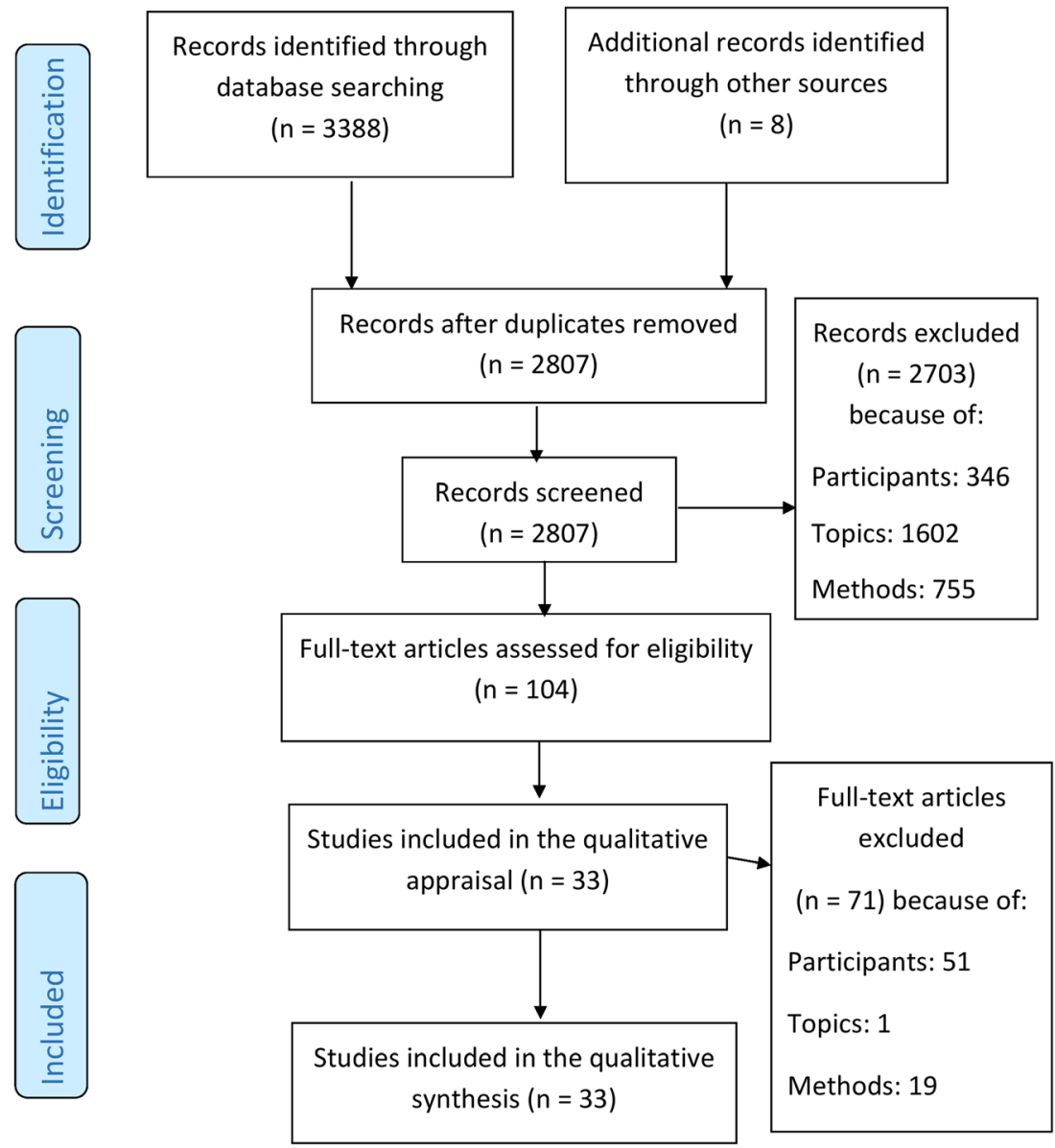

Figure 1 Flow of information through the different phases of study selection. From Moher et al. ${ }^{64}$ 
Table 1 Main Characteristics of the Studies

\begin{tabular}{|c|c|c|c|c|c|c|c|}
\hline References & Year & Aim & Country & Setting & Participants & Data collection & Method \\
\hline Franz et al. ${ }^{25}$ & 2010 & $\begin{array}{l}\text { To describe structural } \\
\text { barriers to mental } \\
\text { health specialists and } \\
\text { consequences of } \\
\text { these barriers on care } \\
\text { for patients with } \\
\text { dementia }\end{array}$ & USA & $\begin{array}{l}\text { Northern California } \\
\text { hospital }\end{array}$ & $\begin{array}{l}\text { Physicians } \\
(N=40)\end{array}$ & $\begin{array}{l}\text { Open-ended } \\
\text { interviews }\end{array}$ & Thematic analysis \\
\hline $\begin{array}{l}\text { Petek, Gajsek, } \\
\text { and Ster }\end{array}$ & 2016 & $\begin{array}{l}\text { To explore the } \\
\text { options and } \\
\text { capabilities of } \\
\text { women general } \\
\text { practitioner specialist } \\
\text { trainees in } \\
\text { coordinating their } \\
\text { family and career }\end{array}$ & Slovenia & $\begin{array}{l}\text { Women GP } \\
\text { specialist trainee } \\
\text { from the national } \\
\text { training program. }\end{array}$ & $\begin{array}{l}\text { Physicians } \\
(N=10)\end{array}$ & $\begin{array}{l}\text { SSI and in- } \\
\text { depth inter- } \\
\text { views }\end{array}$ & Phenomenological \\
\hline $\begin{array}{l}\text { Hasbrouck and } \\
\text { Waddimba }^{27}\end{array}$ & 2017 & $\begin{array}{l}\text { To identify } \\
\text { practitioners' } \\
\text { subjective } \\
\text { perceptions of } \\
\text { predominant stressors } \\
\text { in their work lives }\end{array}$ & USA & $\begin{array}{l}1 \text { teaching hospital, } \\
6 \text { community } \\
\text { hospitals, } 31 \\
\text { outreach clinics, a } \\
\text { long-term care fa- } \\
\text { cility, and } 20 \\
\text { school-based health } \\
\text { centers }\end{array}$ & $\begin{array}{l}\text { Physicians } \\
(N=308)\end{array}$ & $\begin{array}{l}\text { Written answers } \\
\text { to open-ended } \\
\text { questionnaire } \\
\text { items }\end{array}$ & Thematic analysis \\
\hline Beng et al. ${ }^{28}$ & 2015 & $\begin{array}{l}\text { To explore the } \\
\text { subjective } \\
\text { experiences of stress } \\
\text { of both doctors and } \\
\text { nurses providing } \\
\text { palliative care }\end{array}$ & Malaysia & $\begin{array}{l}\text { University Malaya } \\
\text { Medical Centre of } \\
\text { Kuala Lumpur }\end{array}$ & $\begin{array}{l}\text { Physicians } \\
(N=10)\end{array}$ & $\begin{array}{l}\text { Semi-structured } \\
\text { interviews (SSI) }\end{array}$ & Thematic analysis \\
\hline $\begin{array}{l}\text { Ciceklioğlu } \\
\text { et al. }\end{array}$ & 2014 & $\begin{array}{l}\text { To obtain a deep } \\
\text { understanding of how } \\
\text { family physicians } \\
\text { experienced the } \\
\text { process of reforms by } \\
\text { focusing on working } \\
\text { conditions related to } \\
\text { organizational stress }\end{array}$ & Turkey & $\begin{array}{l}\text { The participation of } \\
\text { all categories of } \\
\text { primary care } \\
\text { personnel }\end{array}$ & $\begin{array}{l}\text { Family } \\
\text { physicians } \\
(N=51)\end{array}$ & $\begin{array}{l}36 \text { in-depth in- } \\
\text { terviews and } 4 \\
\text { FG }\end{array}$ & Phenomenological \\
\hline $\begin{array}{l}\text { Flowerdew } \\
\text { et al. }\end{array}$ & 2012 & $\begin{array}{l}\text { To identify key } \\
\text { stressors for } \\
\text { emergency } \\
\text { department staff }\end{array}$ & UK & $\begin{array}{l}\text { Emergency } \\
\text { department of a } \\
\text { London teaching } \\
\text { hospital }\end{array}$ & $\begin{array}{l}\text { Physicians } \\
(N=11) \\
\text { Residents } \\
(N=5)\end{array}$ & SSI & Thematic analysis \\
\hline $\begin{array}{l}\text { Iversen, Farmer, } \\
\text { and Hannaford }^{31}\end{array}$ & 2002 & $\begin{array}{l}\text { To examine whether } \\
\text { there are workload } \\
\text { pressures, as reported } \\
\text { by healthcare } \\
\text { professionals, which } \\
\text { are unique to rural } \\
\text { general practice }\end{array}$ & UK & $\begin{array}{l}\text { General practice } \\
\text { teams located in } \\
\text { different } \\
\text { geographical areas } \\
\text { (urban and rural) }\end{array}$ & $\begin{array}{l}\text { General } \\
\text { practitioners } \\
(\mathrm{GP})(N=16)\end{array}$ & $\begin{array}{l}\text { SSI and an } \\
\text { observation day } \\
\text { in each practice } \\
\text { Iterative } \\
\text { approach }\end{array}$ & Phenomenological \\
\hline $\begin{array}{l}\text { McGowan } \\
\text { et al. }\end{array}$ & 2013 & $\begin{array}{l}\text { To identify the } \\
\text { individual and } \\
\text { organizational factors } \\
\text { impacting on quality } \\
\text { of care and patient } \\
\text { safety }\end{array}$ & Ireland & $\begin{array}{l}\text { Irish teaching } \\
\text { hospitals }\end{array}$ & $\begin{array}{l}\text { Physicians } \\
(N=20)\end{array}$ & $\begin{array}{l}\text { SSI and in- } \\
\text { depth inter- } \\
\text { views }\end{array}$ & $\begin{array}{l}\text { Thematic analysis }+ \\
\text { NVivo }\end{array}$ \\
\hline Picard et al. ${ }^{33}$ & 2015 & $\begin{array}{l}\text { To examine how } \\
\text { residents in general } \\
\text { practice evaluate the } \\
\text { link between burnout } \\
\text { and empathy }\end{array}$ & France & Paris University & $\begin{array}{l}\text { Residents } \\
(N=24)\end{array}$ & SSI & Thematic analysis \\
\hline Turk et al. ${ }^{34}$ & 2013 & $\begin{array}{l}\text { To explore the link } \\
\text { between } \\
\text { organizational } \\
\text { culture, burnout and } \\
\text { quality of care }\end{array}$ & Turkey & University hospital & $\begin{array}{l}\text { Physicians } \\
(N=14)\end{array}$ & $\begin{array}{l}\text { SSI and focus } \\
\text { groups }\end{array}$ & Thematic analysis \\
\hline $\begin{array}{l}\text { Post and } \\
\text { Weddington }^{35}\end{array}$ & 2000 & $\begin{array}{l}\text { To examine the } \\
\text { nature of work- } \\
\text { related stress and } \\
\text { coping experienced } \\
\text { by African-American } \\
\text { family physicians }\end{array}$ & USA & $\begin{array}{l}\text { African-American } \\
\text { family physicians } \\
\text { across the state of } \\
\text { Ohio }\end{array}$ & $\begin{array}{l}\text { Physicians } \\
(N=10)\end{array}$ & SSI & Phenomenological \\
\hline Spinelli et al. ${ }^{36}$ & 2016 & $\begin{array}{l}\text { To explore the } \\
\text { experiences of family } \\
\text { physicians caring for } \\
\text { women using illicit }\end{array}$ & USA & $\begin{array}{l}\text { Group of inner-city } \\
\text { family physicians }\end{array}$ & $\begin{array}{l}\text { Physicians } \\
(N=44)\end{array}$ & Focus group & Phenomenological \\
\hline
\end{tabular}


Table 1. (continued)

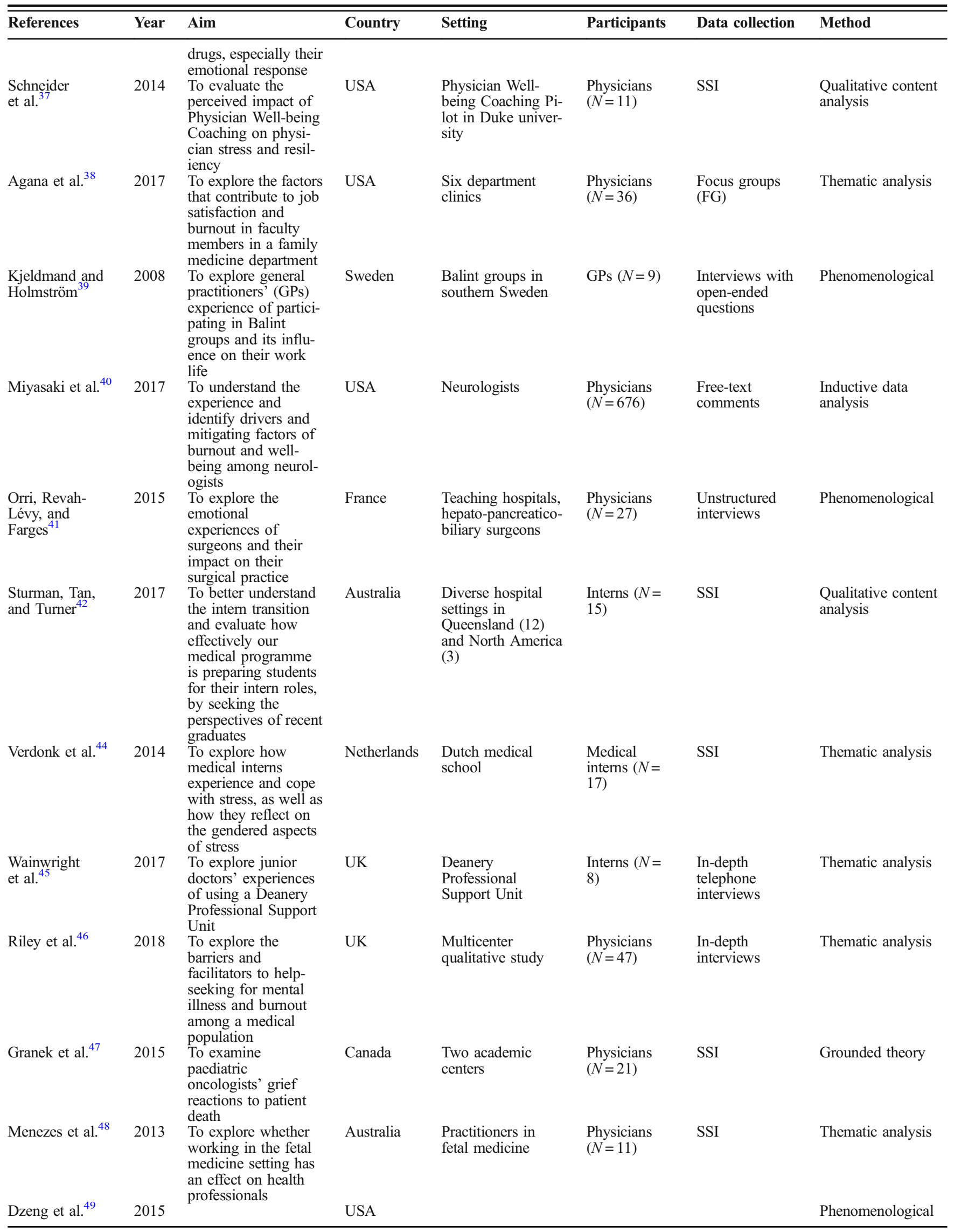


Table 1. (continued)

\begin{tabular}{|c|c|c|c|c|c|c|c|}
\hline References & Year & Aim & Country & Setting & Participants & Data collection & Method \\
\hline & & $\begin{array}{l}\text { To investigate } \\
\text { physician trainees' } \\
\text { experiences and } \\
\text { attitudes regarding } \\
\text { medical practices and } \\
\text { treatments at the end } \\
\text { of life }\end{array}$ & & $\begin{array}{l}\text { Three American } \\
\text { academic medical } \\
\text { centers }\end{array}$ & $\begin{array}{l}\text { Residents } \\
(N=22)\end{array}$ & $\begin{array}{l}\text { SSI and depth } \\
\text { qualitative } \\
\text { interviews }\end{array}$ & \\
\hline $\begin{array}{l}\text { Zambrano } \\
\text { et al. }\end{array}$ & 2014 & $\begin{array}{l}\text { To explore the } \\
\text { experiences, coping } \\
\text { mechanisms, and } \\
\text { impact of death and } \\
\text { dying on palliative } \\
\text { medicine specialists } \\
\text { when dealing with } \\
\text { their patients at the } \\
\text { end of life }\end{array}$ & Australia & $\begin{array}{l}\text { Palliative medicine } \\
\text { unit }\end{array}$ & $\begin{array}{l}\text { Physicians } \\
(N=7)\end{array}$ & $\begin{array}{l}\text { Open-ended, in- } \\
\text { depth inter- } \\
\text { views }\end{array}$ & Thematic analysis \\
\hline $\begin{array}{l}\text { Gwala-Ngozo } \\
\text { et al. }\end{array}$ & 2010 & $\begin{array}{l}\text { To investigate the } \\
\text { experiences of } \\
\text { doctors who perform } \\
\text { elective surgical } \\
\text { procedures in an area } \\
\text { with a high incidence } \\
\text { of HIV and AIDS }\end{array}$ & $\begin{array}{l}\text { South } \\
\text { Africa }\end{array}$ & General hospital & $\begin{array}{l}\text { Physicians } \\
(N=14)\end{array}$ & SSI & Phenomenological \\
\hline $\begin{array}{l}\text { Fitzgerald } \\
\text { et al. }\end{array}$ & 2017 & $\begin{array}{l}\text { To explore the } \\
\text { experience of } \\
\text { psychological distress } \\
\text { and well-being in } \\
\text { emergency medicine } \\
\text { consultants }\end{array}$ & UK & $\begin{array}{l}\text { Emergency } \\
\text { medicine } \\
\text { department }\end{array}$ & $\begin{array}{l}\text { Physicians } \\
(N=18)\end{array}$ & SSI & $\begin{array}{l}\text { Interpretative } \\
\text { phenomenological } \\
\text { analysis (IPA) }\end{array}$ \\
\hline Verhoef et al. ${ }^{53}$ & 2015 & $\begin{array}{l}\text { To explore the impact } \\
\text { of the disciplinary } \\
\text { process and imposed } \\
\text { measures on } \\
\text { healthcare } \\
\text { professionals }\end{array}$ & Netherlands & $\begin{array}{l}\text { Disciplinary } \\
\text { tribunal }\end{array}$ & $\begin{array}{l}\text { Physicians } \\
(N=12)\end{array}$ & SSI & $\begin{array}{l}\text { Inductive qualitative } \\
\text { content analysis }\end{array}$ \\
\hline Cheshire et al. ${ }^{54}$ & 2017 & $\begin{array}{l}\text { To explore GPs' } \\
\text { experiences of } \\
\text { workplace challenges } \\
\text { and stresses, and their } \\
\text { coping strategies, } \\
\text { particularly focusing } \\
\text { on understanding the } \\
\text { impact of recent NHS } \\
\text { workplace changes }\end{array}$ & England & $\begin{array}{l}\text { Recruitment by the } \\
\text { Royal College of } \\
\text { General } \\
\text { Practitioners, } \\
\text { especially at a } \\
\text { resilience talk in } \\
\text { Glasgow, flyers, } \\
\text { contacts, } \\
\text { snowballing }\end{array}$ & $\begin{array}{l}\text { Physicians } \\
(N=22)\end{array}$ & $\begin{array}{l}\text { FG + one-to- } \\
\text { one telephone } \\
\text { interviews }\end{array}$ & Thematic analysis \\
\hline $\begin{array}{l}\text { Lindfors, } \\
\text { Boman, and } \\
\text { Alexanderson }^{55}\end{array}$ & 2012 & $\begin{array}{l}\text { To gain knowledge of } \\
\text { stress-coping strate- } \\
\text { gies used by academ- } \\
\text { ic physicians. }\end{array}$ & Sweden & $\begin{array}{l}\text { Academic } \\
\text { physicians } \\
\text { employed at a } \\
\text { university hospital }\end{array}$ & $\begin{array}{l}\text { Physicians } \\
(N=17)\end{array}$ & $\begin{array}{l}\text { Three-part } \\
\text { focus group } \\
\text { interviews }\end{array}$ & Grounded theory \\
\hline Swetz et al. ${ }^{56}$ & 2009 & $\begin{array}{l}\text { To explore strategies } \\
\text { for avoiding burnout } \\
\text { and finding fulfilment } \\
\text { in palliative medicine }\end{array}$ & USA & $\begin{array}{l}\text { The American } \\
\text { Academy of } \\
\text { Hospice and } \\
\text { Palliative Medicine } \\
\text { website }\end{array}$ & $\begin{array}{l}\text { Physicians } \\
(N=30)\end{array}$ & $\begin{array}{l}\text { Qualitative } \\
\text { online } \\
\text { multiquestion/ } \\
\text { single-answer } \\
\text { survey }\end{array}$ & Thematic analysis \\
\hline $\begin{array}{l}\text { Woolhouse } \\
\text { et al. }\end{array}$ & 2012 & $\begin{array}{l}\text { To explore the } \\
\text { experiences of a } \\
\text { group of inner-city } \\
\text { family physicians } \\
\text { caring for women } \\
\text { using illicit drugs }\end{array}$ & Canada & $\begin{array}{l}\text { Family physicians } \\
\text { working in Toronto } \\
\text { or Ottawa }\end{array}$ & $\begin{array}{l}\text { Physicians } \\
(N=10)\end{array}$ & $\begin{array}{l}\text { In-depth } \\
\text { interviews }\end{array}$ & Phenomenological \\
\hline $\begin{array}{l}\text { Zwack and } \\
\text { Schweitzer }^{58}\end{array}$ & 2013 & $\begin{array}{l}\text { To identify health- } \\
\text { promoting strategies } \\
\text { employed by experi- } \\
\text { enced physicians in } \\
\text { order to define proto- } \\
\text { typical resilience pro- } \\
\text { cesses and key } \\
\text { aspects of resilience } \\
\text { fostering preventive } \\
\text { actions }\end{array}$ & Germany & $\begin{array}{l}\text { University Hospital } \\
\text { Heidelberg }\end{array}$ & $\begin{array}{l}\text { Physicians } \\
(N=200)\end{array}$ & SSI & $\begin{array}{l}\text { Content Analysis } \\
\text { method }\end{array}$ \\
\hline
\end{tabular}

the literature: feelings of exhaustion, chronic fatigue, decreased motivation, mood swings, irritability, low tolerance for stress, apathy, vulnerability to psychosomatic symptoms, and sadness ${ }^{25,26}$. 
Table 2 CASP Summary

\begin{tabular}{|c|c|c|c|c|}
\hline \multirow[t]{2}{*}{ Criteria } & \multirow[t]{2}{*}{ Example } & \multicolumn{3}{|c|}{$\begin{array}{l}\text { Quality assessment of studies } \\
\text { (summary) }\end{array}$} \\
\hline & & $\begin{array}{l}\text { Met } \\
\text { criterion }\end{array}$ & $\begin{array}{l}\text { Partially } \\
\text { met }\end{array}$ & $\begin{array}{l}\text { Did } \\
\text { not } \\
\text { meet }\end{array}$ \\
\hline Aims & $\begin{array}{l}\text { Explicitly stated } \\
\text { aims/objectives of } \\
\text { research }\end{array}$ & 33 & 0 & 0 \\
\hline Method & $\begin{array}{l}\text { Appropriate use of } \\
\text { qualitative methods }\end{array}$ & 33 & 0 & 0 \\
\hline $\begin{array}{l}\text { Research } \\
\text { design }\end{array}$ & $\begin{array}{l}\text { Justification of the } \\
\text { specific research } \\
\text { design }\end{array}$ & 33 & 0 & 0 \\
\hline Sampling & $\begin{array}{l}\text { Appropriate } \\
\text { sampling strategy, } \\
\text { description of } \\
\text { recruitment, } \\
\text { discussion around } \\
\text { recruitment }\end{array}$ & 32 & 1 & 0 \\
\hline $\begin{array}{l}\text { Data } \\
\text { collection }\end{array}$ & $\begin{array}{l}\text { Appropriate } \\
\text { description of data } \\
\text { collection methods }\end{array}$ & 33 & 0 & 0 \\
\hline Reflexivity & $\begin{array}{l}\text { Critical examination } \\
\text { of researchers' own } \\
\text { role and potential } \\
\text { bias in data } \\
\text { collection and } \\
\text { analysis }\end{array}$ & 12 & 5 & 16 \\
\hline $\begin{array}{l}\text { Ethical } \\
\text { issues }\end{array}$ & $\begin{array}{l}\text { Evidence of } \\
\text { approval by an } \\
\text { appropriate body }\end{array}$ & 22 & 8 & 3 \\
\hline $\begin{array}{l}\text { Data } \\
\text { analysis }\end{array}$ & $\begin{array}{l}\text { Adequate and in- } \\
\text { depth description of } \\
\text { analysis process, } \\
\text { sufficiently rigor- } \\
\text { ous data analysis }\end{array}$ & 33 & 0 & 0 \\
\hline Findings & $\begin{array}{l}\text { Clear statement of } \\
\text { the findings, } \\
\text { discussion of } \\
\text { evidence, } \\
\text { credibility, integrity }\end{array}$ & 33 & 0 & 0 \\
\hline $\begin{array}{l}\text { Value of } \\
\text { research }\end{array}$ & $\begin{array}{l}\text { Contribution to } \\
\text { existing } \\
\text { knowledge, } \\
\text { transferability }\end{array}$ & 33 & 0 & 0 \\
\hline
\end{tabular}

\section{The Stress Factors Associated with the Onset of Burnout}

The doctors included in these studies reported numerous stress factors that could promote the onset of burnout.

Organizational Factors. The physicians in these studies recognized organizational difficulties as the stress factors contributing the most to burnout ${ }^{27}$.

Nearly all the studies reported aspects of burnout associated with the organization of work. The doctors noted especially workloads that were too high ${ }^{25,26,28-34}$ and especially the load of paperwork ${ }^{29,35,36}$ and insufficiently diversified work $^{37}$.

The theme of time recurred repeatedly: the doctors reported workdays that were too long, the constant need to do things faster $^{32,38,39-41}$, as well as a lack of time $e^{29,32,37}$, in particular to spend with patients, for continued education, and to have a social life ${ }^{26,34}$. Heavy workloads and lack of time were directly related to the difficulty many of these doctors had in finding a balance between their personal and working lives ${ }^{21,32,40,41}$.
Table 3 Quotations

\begin{tabular}{lll}
\hline \hline Themes & $\begin{array}{l}\text { Quotations from } \\
\text { participants in primary } \\
\text { studies }\end{array}$ & $\begin{array}{l}\text { Interpretations of } \\
\text { findings offered by } \\
\text { authors }\end{array}$ \\
\hline
\end{tabular}

1. Stress factors associated with the onset of burnout

1.1 Organizational factors

"We have a legal right to

30 days annual leave.

However, I cannot take even

20 days. You cannot leave

without finding someone to

fill your place."

"I've always said I would gladly see twice as many people if I could see them, treat them, and then walk out of the room and have nothing else to do." $" 36$ "I believe that patients approach women differently. You have to prove yourself more as a woman. They do not trust you as quickly as they trust men and think that you are a nurse."

\subsection{Relational factors}

"We explain that the condition is actually quite bad, and the survival is not so good. But some relatives are so much attached to patients that they do not want to accept it. They want us to do everything. There goes the conflict." ${ }^{28}$. "I do not want to communicate as much because I know they are stressed"; "I know they are really busy and I attempt to do things myself." 3

"You're emotionally preoccupied when you get home sometimes and you are still thinking about things and wondering whether you did the right thing. I find myself sometimes waking up in the night thinking 'did I make up that diaphragmatic hernia or was it really there?",48.

\subsection{Individual factors}

"I do not relive being in front of the disciplinary board anymore. For about a year I would wake up every night at $3 \mathrm{AM}$ and would start to explain what had happened." "It's a very negative experience and it's annoying for the family as
Interestingly, respondents acknowledged that their working conditions might affect their work

performance, on occasion. However, they did not appear to be concerned about the impact of these conditions on their own well-being ${ }^{32}$.

These tensions were described as originating from the clinicians' experience of new requirements in the work environment, the tension between direct patient care and non-direct patient care tasks, and the "e-stress" caused by the digital presence in providers' work lives. Several authors have reported on the impact of workplace stressors on provider burnout ${ }^{36}$.

The conceptualisation of the Model as a continuum of problems in caring for others at one end and problems in caring for oneself at another. In this study, the difficulties of being careful are linked to organizational problems.

This study supports the existence of a relation between difficulty in caring for others and the absence of self-care ${ }^{28}$.

The two most common stressors, excessive workload and staff shortages, may be considered two sides of the same problem, that is, an imbalance between workload and resources. By definition, stress occurs when a person perceives that demand exceeds available resources. This imbalance is exacerbated by government targets, where time pressure becomes an issue in addition to clinical need ${ }^{30}$.

This study showed an association between complaint procedures and risks of depression, anxiety, and suicidal ideation.

Another study revealed that anger, distress, and the feeling of being personally 
Table 3. (continued)

\begin{tabular}{lll}
\hline \hline Themes & $\begin{array}{l}\text { Quotations from } \\
\text { participants in primary } \\
\text { studies }\end{array}$ & $\begin{array}{l}\text { Interpretations of } \\
\text { findings offered by } \\
\text { authors }\end{array}$ \\
\hline
\end{tabular}

well. It gets you down and almost makes you depressed, although you get over it as well." ${ }^{3}$

2 . The protective factors of burnout

2.1 Individual factors

"I see that I can hang in there by having a definite goal, a set timeframe till the exam. I hope that as a resident I will know how to manage my work conditions and other things so that working in my own clinic will be different." 26

"I try to meet up with my friend who lives in the village every Thursday, we go for a coffee or a fruit cup and we have that hour to ourselves. Then I come home and dive in with full power. I always have it in the back of my head that I need to do something for myself as well, even though I need to speed things up afterwards to finish everything I had set out."26 "Create a calendar and set aside time for exercise and yourself each week." "Faith activities including prayer for my patients, their families and myself." 56

2.2 Relational factors

\section{"Being part of a}

team - recognising you do not need to carry the burden alone."

"My success has come from the support and mentoring of colleagues in the field, and the understanding by senior hospital and health system officials of the importance of offering palliative care services." 56

"We are torturing this poor gentleman; that is really all we are doing. I do vaguely feel uncomfortable about the general gestalt of what we do in the ICU to people at the end of life. I feel morally sick to my stomach about it of course. Some of what we do is awful, but some of those things have also given me the skills to resuscitate [others]. I do not mean to justify the torture that we put our elderly critically ill and dying through, but it did provide me with many learning opportunities to help people who then could be saved." 48

attacked are common responses to litigation ${ }^{53}$.

The crucial factor for achieving an effective balance is the empowerment of women doctors, which is enabled through a positive attitude towards self ${ }^{27}$.

This finding suggests the need for multiple outlets for wellness and

decompression. The most common approach reported is related to exercise and physical well-being, closely followed by nurturing professional relationships

and taking a

"transcendental perspective. The latter approach is consistent with previous studies which have suggested that "daily spiritual experiences" may help professionals engaged in end-of-life care to mitigate burnout ${ }^{12}$ and speaks to strong mind-body philosophy while taking care of oneself is critical to optimally care for others ${ }^{56}$.

The interdisciplinary team (IDT) is a hallmark of delivering high-quality palliative care; hence, building relationships and promoting teamwork within the IDT is thought to be essential. This includes a strong sense of sharing workload and recognizing one's personal limitations, and that utilizing IDT col-

leagues may minimize risk of burnout ${ }^{56}$

Physician trainees

experienced significant moral distress when they felt obligated to provide treatments at or near the end of life that they believed to be futile. Some trainees developed detached and

dehumanizing attitudes towards patients as a coping mechanism, which may contribute to a loss of empathy ${ }^{48}$.

(continued on next page)

Finally, they described problems with those above them in the hospital chain of command ${ }^{27,29,36,42}$, lack of continuing
Table 3. (continued)

\begin{tabular}{|c|c|c|}
\hline Themes & $\begin{array}{l}\text { Quotations from } \\
\text { participants in primary } \\
\text { studies }\end{array}$ & $\begin{array}{l}\text { Interpretations of } \\
\text { findings offered by } \\
\text { authors }\end{array}$ \\
\hline 2.3 Org & $\begin{array}{l}\text { nizational factors } \\
\text { "I think the way the team } \\
\text { works under pressure is a } \\
\text { factor of how the team } \\
\text { leadership works under } \\
\text { pressure."30. } \\
\text { "Palliative care is } \\
\text { extraordinarily draining, so I } \\
\text { find the key to a long career } \\
\text { in this field is balance ... } \\
\text { research, writing and } \\
\text { teaching...." }\end{array}$ & $\begin{array}{l}\text { Leadership and teamwork } \\
\text { appear to be mediating } \\
\text { factors between objective } \\
\text { stress and the subjective } \\
\text { experience. So, stress is not } \\
\text { only dependent on the } \\
\text { realities of workload, but } \\
\text { also strongly influenced by } \\
\text { how a team and team } \\
\text { leader deal with it } t^{30} \text {. } \\
\text { The results of our } \\
\text { qualitative study illustrate } \\
\text { several key findings. First, } \\
\text { those surveyed reported } \\
\text { using a variety of wellness } \\
\text { strategies (median of at } \\
\text { least four). This finding } \\
\text { suggests the need for } \\
\text { multiple outlets for } \\
\text { wellness and } \\
\text { decompression }\end{array}$ \\
\hline
\end{tabular}

education $^{25,32,34}$, and the lack or unreplaced absence of healthcare personnel ${ }^{27,30,32,43}$.

Doctors underlined the importance of context: both the social context and that of their medical practice. Accordingly, age, sex, and skin color could generate stressful situations. The young physicians reported stress that they considered inherent in their lack of knowledge and experience ${ }^{42,44,45}$; women described inequalities in terms of opportunity, recognition, and credibility ${ }^{34,44}$ as well as sexual harassment in the workplace $^{34}$. Finally, some authors pointed out the experiences of discrimination and racism endured by black doctors ${ }^{35}$.

Physicians also reported some particular workplaces or situations that were especially stressful. These included all types of situations associated with isolation ${ }^{29,31,46}$. Similarly, three medical situations were noted: (i) directly facing death $^{28,47,48}$ or the end of life ${ }^{49,50}$; (ii) risk-taking, especially in surgery ${ }^{51,41}$; and (iii) the complexity of situations with comorbidity or entanglement with social factors ${ }^{28}$.

Finally, participants very frequently raised the issue of poor working conditions ${ }^{28,29,52}$, which could involve either material conditions, such as inadequate equipment ${ }^{32,51}$ or the precarity of some doctors' status, associated with substantial concern about their future ${ }^{29,32,34}$.

Relational Factors. Doctors reported fairly frequently that relational difficulties between professionals caused substantial stress. These could concern disagreements or differences of opinions between providers ${ }^{28}$ or a vague definition of their respective roles ${ }^{34}$. The younger physicians described difficult relationships with senior doctors: they described communication problems, even misunderstanding between them ${ }^{30,42}$

Many doctors also described inordinate emotional investment with patients and their relatives: too much 
Table 4 List of Stress and Protective Factors

\begin{tabular}{|c|c|c|}
\hline Factors & $\begin{array}{l}\text { Number of } \\
\text { studies }\end{array}$ & References \\
\hline \multicolumn{3}{|l|}{ Stress factor } \\
\hline \multicolumn{3}{|l|}{ Organizational factors } \\
\hline High workloads & 9 & $20,21,23-29$ \\
\hline Load of paperwork & 3 & $24,30,31$ \\
\hline Insufficiently diversified work & 1 & \\
\hline The constant need to do things & 5 & $27,33,35-37$ \\
\hline \multicolumn{3}{|l|}{ faster } \\
\hline Lack of time & 5 & $21,24,27,29,32$ \\
\hline $\begin{array}{l}\text { The hospital chain of } \\
\text { command }\end{array}$ & & $22,24,31,38$ \\
\hline Lack of continuing education & 3 & $20,27,29$ \\
\hline Lack of healthcare personnel & 3 & $21,25,27$ \\
\hline $\begin{array}{l}\text { Lack of knowledge and } \\
\text { experience }\end{array}$ & 3 & $38,39,40$ \\
\hline Discriminations & 3 & $29,39,30$ \\
\hline To be isolated & 3 & $24,26,41$ \\
\hline Directly facing death & 5 & $23,42-45$ \\
\hline Risk-taking & 2 & 37,46 \\
\hline Poor working conditions & 6 & $\begin{array}{l}23,24,27,29,46 \\
47\end{array}$ \\
\hline \multicolumn{3}{|l|}{ Relational factors } \\
\hline $\begin{array}{l}\text { Relationship problems in the } \\
\text { team }\end{array}$ & 4 & $23,25,29,38$ \\
\hline Too much empathy & 4 & $23,28,37,43$ \\
\hline Self-sacrifice & 1 & \\
\hline Lack of recognition from both & 3 & $24,28,31$ \\
\hline \multicolumn{3}{|l|}{ patients and family } \\
\hline \multicolumn{3}{|l|}{ Individual Factors } \\
\hline responsibility & 3 & $24,3,40$ \\
\hline $\begin{array}{l}\text { Responsibility for } \\
\text { complications }\end{array}$ & 1 & 37 \\
\hline $\begin{array}{l}\text { Disciplinary measures for } \\
\text { medical errors }\end{array}$ & 1 & 48 \\
\hline Feelings of guilt & 2 & 37,46 \\
\hline Doubts about their abilities & 2 & 27,30 \\
\hline \multirow{2}{*}{\multicolumn{3}{|c|}{$\begin{array}{l}\text { Protective factors } \\
\text { Individual factors }\end{array}$}} \\
\hline Individual factors & & \\
\hline Self-knowledge & 10 & $\begin{array}{l}21,32,35,37,45 \\
49,50-53\end{array}$ \\
\hline Self-care & 10 & $\begin{array}{l}21,23,29,30,32 \\
45,46,50,51,53\end{array}$ \\
\hline Realistic vision of one's work & 7 & $\begin{array}{l}23,25,32,35,50 \\
52\end{array}$ \\
\hline \multicolumn{3}{|l|}{ Relational factors } \\
\hline $\begin{array}{l}\text { Good professional } \\
\text { relationships }\end{array}$ & 6 & $\begin{array}{l}21,25,35,48,51, \\
53\end{array}$ \\
\hline Emotional support between & 8 & $21,25,35,44,4$ \\
\hline colleagues & & $50-52$ \\
\hline Teamwork to avoid isolation & 1 & 52 \\
\hline Group decision-making & 2 & 32,46 \\
\hline Benefits of supervision & 1 & 39 \\
\hline Appropriate distance with & 5 & $23,28,35,44,53$ \\
\hline \multicolumn{3}{|l|}{ patients } \\
\hline Patients' gratitude to them & 1 & 39 \\
\hline Friendships and families & 5 & $21,30,46,50,53$ \\
\hline \multicolumn{3}{|l|}{ Organizational factors } \\
\hline Increase the number of doctors & 1 & \\
\hline $\begin{array}{l}\text { Protocols for strategies to } \\
\text { increase productivity }\end{array}$ & 2 & 25,46 \\
\hline Good leadership & 1 & 25 \\
\hline $\begin{array}{l}\text { Importance of organizing and } \\
\text { managing (enough time to see } \\
\text { patients, long-term permanent } \\
\text { job) }\end{array}$ & 2 & $35,45,50,53$ \\
\hline Diversification of activities & 5 & $32,37,45,50,51$ \\
\hline
\end{tabular}

empathy $^{28,33,41,48}$, even self-sacrifice ${ }^{26}$. They also complained about the lack of recognition from both patients and family $\mathrm{y}^{29,33,36}$.
Individual Factors. The doctors participating in these studies reported very few stress factors directly related to themselves. Some authors insisted on the burden of personal responsibility ${ }^{29,41,51}$. Some underlined the dimensions of decision-making ${ }^{48,52}$, others responsibility for complications ${ }^{41}$, and still others the effects of disciplinary measures for medical errors ${ }^{53}$. They also reported feelings of guilt $^{41,51}$ or helplessness ${ }^{28,49}$, as well as doubts about their abilities $^{32,35}$.

Connections Between Stress Factors. The studies reveal a ranking of and connections between the stress factors that can promote the onset of burnout. Organization was the most recurrent level mentioned in the studies, then relation, and finally individual factors. A structure of experience, within a timeline, can be drawn from this hierarchy. This suggests that a doctor experiences organization as the first level being affected, then relational aspects, and finally himself or herself (Fig. 2).

\section{The Protective Factors}

Most studies also reported protective factors that mirrored the stress factors and could help to prevent physician burnout.

Individual Factors. Regardless of the associated stress factors, most articles reported individual protective factors. We found three that were especially important: (i) self-knowledge, (ii) self-care, and (iii) a realistic vision of one's work.

To protect oneself and cope with stress, doctors underlined the importance of knowing oneself well ${ }^{39,54}$. This involved knowing their abilities and their needs ${ }^{26,55}$, but especially their limitations ${ }^{26,39,50,55-57}$. It required increasing their reflexivity and self-consciousness ${ }^{37,55,58}$ and recognizing and naming their emotions ${ }^{39,41}$.

It was also very important for physicians to take care of themselves ${ }^{26,35,37}$ and to make time for a personal life ${ }^{35,50,58}$ especially for leisure activities ${ }^{34,55,56,58}$. Some studies underlined the importance of physical well-being through a healthy diet and physical activity ${ }^{56,58}$. For psychological wellbeing, physicians mentioned different avenues towards calmness or letting go $^{28}$ : religious beliefs and spiritual practices, meditation, or philosophy ${ }^{26,35,51,56,58}$, or potential recourse to psychological help ${ }^{53}$. Others also underlined the benefits of humor $^{56}$.

Finally, a realistic vision and realistic expectations of their work was also protective ${ }^{37,56,57}$. The doctors highlighted the importance of making choices: ranking tasks, setting priorities, setting achievable objectives, and making compromises and not committing to too many activities ${ }^{28,30,37,55}$. This also meant willingness to refuse tasks and responsibilities ${ }^{37,55}$. It also involve accepting what they could not change ${ }^{58}$ and not being able to do everything for each patient ${ }^{39}$.

Relational Factors. Many studies considered that good professional relationships were an essential protective 

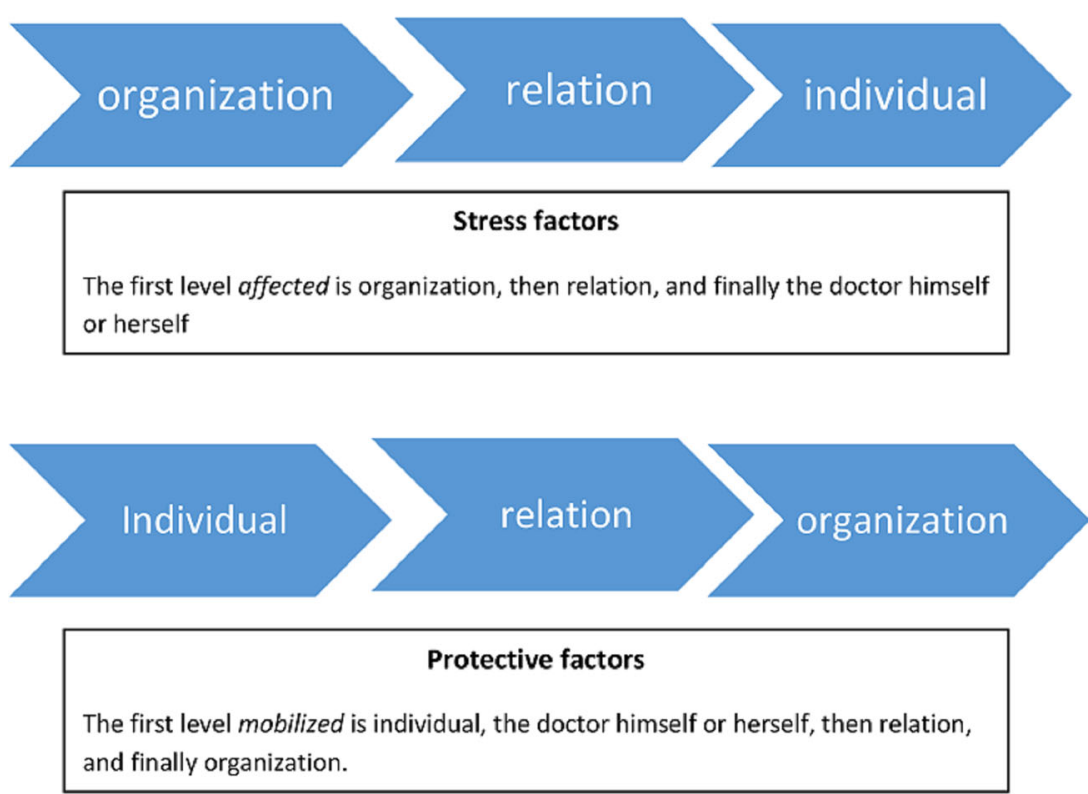

Figure 2 Connection between factors.

factor $^{26,30,53,56,58}$. The physicians underlined especially the importance of dialogue and emotional support between colleagues $26,30,39,49,50,55-57,39$. They also prioritized teamwork to avoid isolation ${ }^{57}$, to enable group decisionmaking ${ }^{37,51}$, and especially to ensure a feeling of safety and satisfaction at work ${ }^{39}$. Finally, they mentioned the benefits of supervision $^{44,26}$.

Strategies to keep relationships with patients at an appropriate distance were frequently reported as a protective factor $^{32,58}$. Some explained that they considered each patient as a whole and listened to them so that they were able to hear their story $^{39}$, see the person behind the symptoms ${ }^{58}$, and explore their expectations and their preferences ${ }^{28}$. Surgeons, on the other hand, reported it was necessary to dehumanize patients - to consider only their body parts or organs - to be able to act $^{49}$.

Some physicians also mentioned protective factors associated with the physician-patient relationship: remembering patients they had cared for ${ }^{56}$ and whose funeral they had attended ${ }^{49}$. Finally, they were sensitive to their patients' gratitude to them ${ }^{44}$.

Most physicians reported that their friendships and families played a major protective role ${ }^{26,55,58}$. They insisted especially on the importance of spending time with them ${ }^{26,55}$, receiving family support ${ }^{26,35,51}$, and having an understanding life partner ${ }^{26}$.

Organizational Factors. Finally, and to a lesser degree, the studies underlined that better organization of work protected doctors from stress. This involves increasing the number of doctors in each department ${ }^{30}$, setting up protocols for management or strategies to increase productivity ${ }^{30,51}$, and good leadership ${ }^{30}$.

We also find here the question of time and the importance of organizing and managing one's time ${ }^{50,55,58}$, especially of having enough time to see patients ${ }^{58}$, and of a long-term permanent job ${ }^{39}$.

Finally, several authors underlined the protective role of diversification of activities (teaching, supervision, and research) $)^{37,41,50,55,56}$.

Connections Between Protective Factors. Contrary to the connections of the stress factors, here, the first, and most, recurrent level mobilized for protection was personal and individual, then the relations mentioned less often, and finally the organization. The structure of experience, as shown in Fig. 2, would be here that doctors first protected themselves individually, by their personal actions, thoughts, and personal qualities. They mobilized then relational aspects, and at last the contextual and organizational level aspects.

\section{DISCUSSION}

Our research found no qualitative study that explicitly explored physicians' experiences of burnout. When this point was considered in the studies included in this metasynthesis, it always involved descriptions or definitions of burnout but never access to experience. Future qualitative research is thus necessary to explore in depth the subjective experience of physicians who have experienced burnout.

Our research found that qualitative studies about physicians' burnout mostly explored contributing and protective factors. Some factors have been already broadly investigated while others have been mentioned in only one study (Table 4) - for instance, self-sacrifice or the impact of medical errors-further research should specifically explore the latter. Furthermore, this metasynthesis provides access to the ranking and connections between the different types of factors, but no 
study directly addressed this important issue. The individual and organizational levels are abundantly described in the literature, simultaneously for risk factors ${ }^{59}$ and interventions ${ }^{13}$. On this subject, a recent meta-analysis ${ }^{13}$ found mainly interventions with an individual focus (mindfulness, stress management, small-group discussions, self-care training, and communication skills training), and few interventions focusing on organization (rotation length, various modifications to clinical work processes, and shortened resident shifts) of similar effectiveness in reducing burnout scores. The authors concluded that interventions combining these two levels are needed ${ }^{13}$.

Our results suggest that doctors identify numerous organizational factors at the origin of potential burnout, but envision protecting themselves individually above all. This is similar to the personality features often associated with images of physicians, such as perfectionism and denial of personal vulnerability, already described as factors predisposing them to burnout ${ }^{12,45}$ and which would also induce them to seek solely individual solutions. We also think that physicians do not know whom they should address - or how - about organizational factors. A recent study considered the loss of a feeling of control as a major contributor to doctors' burnout ${ }^{60}$ and some authors have put forward their loss of autonomy in their practices to "unknown and invisible forces." In other words, doctors may no longer control what happens for or to them at the organizational level and this factor may, besides contributing to burnout, prevent them from acting on it at that level.

The second level of response in our two themes concerns the group and interpersonal relationships, both in the workplace and in their personal lives. The literature also highlights the importance of socialization at work as a protective factor ${ }^{12}$. The importance of this relational and group dimension is consistent with numerous reports on the sociology of work and of social psychology, which have shown the entanglement between individual and group in institutions ${ }^{61}$. The group at the hospital, we think, represents an original axis of protection and intervention for battling burnout in healthcare professionals generally and doctors in particular. That is, burnout must be thought of as an individual experience that takes place within a group. A doctor's experience of burnout must not be considered in individual problem but on the contrary be integrated into the group dimension. Some authors have insisted on the distinction between depression and burnout ${ }^{62,63}$; considering burnout only as an individual experience is equivalent to confusing it with depression, that is, an experience of distress belonging only to the depressed individual.

\section{Strengths and Limitations}

This metasynthesis integrates the experience of 1589 doctors from 15 different countries. The method we applied is rigorous, has been tested in medical research ${ }^{21}$, and meets the criteria of the ENTREQ guidelines ${ }^{23}$. We analyzed 33 articles, all published in peer-reviewed journals and mostly of good quality. Our method is well adapted to the synthesis of a large number of qualitative studies and enabled us to reach a much broader perspective than any of the initial studies.

Nonetheless, certain aspects of this metasynthesis limit the generalization of its conclusions. A qualitative metasynthesis collects only partial data from the participants and depends on the researchers' interpretations of the data. Moreover, although the review assembled articles from diverse cultural areas, English-speaking countries are overrepresented as we restricted our selection to articles in that language and ours, for practical reasons. We might have excluded studies from language other than French and English and therefore reinforced this overrepresentation. Finally, this work focused only on qualitative literature and did not integrate studies about interventions. It would be very useful to study which factors are linked with which interventions so to elicit what the contributing factors left aside are.

\section{CONCLUSION}

This metasynthesis provides access to what doctors identify as contributing factors to burnout and how they envision protecting themselves from it. Relational factors should be addressed as an original axis of protection and intervention for battling doctors' burnout.

Acknowledgments: The authors wish to thank Jo Ann Cahn for the translation.

Corresponding Author: Jordan Sibeoni, MD, PhD; Service Universitaire de Psychiatrie de l'Adolescent Argenteuil Hospital Centre, 69 rue du LTC Prud'hon 95107, Argenteuil, France (e-mail: Jordan.sibeoni@ch-argenteuil.fr).

\section{Compliance with Ethical Standards:}

Conflict of Interest: The authors declare that they do not have a conflict of interest.

\section{REFERENCES}

1. Maslach C, Leiter MP. The truth about burnout: How organizations cause personal stress and what to do about it. San Francisco, CA, US :Josey Bass ; 1997, 200 p.

2. West CP, Shanafelt TD, Kolars JC. Quality of life, burnout,educational debt, and medical knowledge among internal medicine residents. JAMA. 2011;306(9):952-960. doi: https://doi.org/10.1001/jama.2011.1247

3. Shanafelt TD, Hasan O, Dyrbye LN, et al. Changes in Burnout and Satisfaction with Work-Life Balance in Physicians and the General US Working Population between 2011 and 2014. Mayo Clinic Proc. 2015;90(12):1600-1613. doi:https://doi.org/10.1016/j.mayocp.2015. 08.023

4. Fahrenkopf AM, Sectish TC, Barger LK, et al. Rates of medication errors among depressed and burnt out residents: Prospective cohort study. BMJ. 2008;336:488-491. doi:https://doi.org/10.1136/bmj. 39469.763218.BE

5. West CP, Dyrbye LN, Sloan JA, et al. Single Item Measures of Emotional Exhaustion and Depersonalization Are Useful for Assessing Burnout in Medical Professionals. J Gen Intern Med. 2009;24(12):1318-1321. doi:https://doi.org/10.1007/s11606-009-1129-Z 
6. Ariely D, Lanier WL. Disturbing Trends in Physician Burnout and Satisfaction with Work-Life Balance Dealing with Malady among the Nation's Healers. Mayo Clinic Proceedings. 2015;90(12):1593-1596. doi:https://doi.org/10.1016/j.mayocp.2015.10.004

7. Dewa CS, Loong D, Bonato S, et al. How does burnout affect physician productivity? A systematic literature review. BMC Health Serv Res. 2014;14(325). doi:https://doi.org/10.1186/1472-6963-14-325

8. Shanafelt TD, Goh J, Sinsky C. The Business Case for Investing in Physician Well-being. JAMA Intern Med. 2017;177(12):1826-1832. doi:https://doi.org/10.1001/jamainternmed.2017.4340

9. Shanafelt TD, Balch CM, Dyrbye LN, et al. (2011). Special report: suicidal ideation among American surgeons. Arch Surg. 2011;146(1): 54 62. doi: https://doi.org/10.1001/archsurg.2010.292

10. West CP, Tan AD, Shanafelt TD. Association of resident fatigue and distress with occupational blood and body fluid exposures and motor vehicle incidents. Mayo Clin Proc. 2012;87(12):1138-1144. doi: https:// doi.org/10.1016/j.mayocp.2012.07.021

11. Lee RT, Seo B, Hladkyj S, et al. Correlates of physician burnout across regions and specialties: A meta-analysis. Hum Resour Health. 2013;28:11-48. doi:https://doi.org/10.1186/1478-4491-11-48

12. Gazelle G, Liebschutz JM, Riess H. Physician Burnout: Coaching a Way Out. J Gen Intern Med, 2015;30(4):508-513. doi:https://doi.org/10. 1007/s11606-014-3144-y

13. West CP, Dyrbye LN, Erwin PJ, et al. Interventions to prevent and reduce physician burnout: a systematic review and meta-analysis. Lancet 2016;388(10057):2272-2281. doi:https://doi.org/10.1016/S0140 6736(16)31279-X

14. Noyes J, Lewin S. Chapter 6: Supplemental Guidance on Selecting a Method of Qualitative Evidence Synthesis, and Integrating Qualitative Evidence with Cochrane Intervention Reviews. In Supplementary Guidance for Inclusion of Qualitative Research. Cochrane Systematic Reviews of Interventions. 2011.

15. Morton RL, Tong A, Howard $\mathbf{K}$, et al. The views of patients and carers in treatment decision making for chronic kidney disease: systematic review and thematic synthesis of qualitative studies. BMJ. 2010;340:c112.

16. Bousquet G, Orri M, Winterman S, Brugiere C, Verneuil L, Revah-Levy A. Breaking Bad News in Oncology: A Metasynthesis. Journal of Clinical Oncology. 2015 Aug 1;33(22):2437-43.

17. Lachal J, Orri M, Speranza M, Falissard B, Lefevre H, QUALIGRAMH, et al. Qualitative studies among obese children and adolescents: a systematic review of the literature. Obes Rev. 2013 May;14(5):351-368.

18. Lachal J, Orri M, Sibeoni J, Moro MR, Revah-Levy A. Metasynthesis of Youth Suicidal Behaviours: Perspectives of Youth, Parents, and Health Care Professionals. Dalal K, editor. PLOS ONE. 2015 May 22;10(5):e0127359.

19. Sibeoni J, Orri M, Colin S, Valentin M, Pradère J, Revah-Levy A. The lived experience of anorexia nervosa in adolescence, comparison of the points of view of adolescents, parents, and professionals: A metasynthesis. International Journal of Nursing Studies. 2017 Jan;65:25-34.

20. Sibeoni J, Orri M, Valentin M, Podlipski M-A, Colin S, Pradere J, et al. Metasynthesis of the Views about Treatment of Anorexia Nervosa in Adolescents: Perspectives of Adolescents, Parents, and Professionals. PLoS ONE. 2017;12(1):e0169493.

21. Atkins $\mathbf{S}$, Lewin $\mathbf{S}$, Smith $\mathbf{H}$, et al. Conducting a meta-ethnography of qualitative literature: Lessons learnt. BMC Med Res Methodol. 2008;8(1) doi:https://doi.org/10.1186/1471-2288-8-21

22. Thomas J, Harden A. Methods for the thematic synthesis of qualitative research in systematic reviews. BMC Med Res Methodol. 2008;8(45). doi:https://doi.org/10.1186/1471-2288-8-45

23. Tong A, Flemming $\mathbf{K}$, McInnes E, et al. Enhancing transparency in reporting the synthesis of qualitative research: ENTREQ. BMC Med Res Methodol. 2012;12(181). doi:https://doi.org/10.1186/1471-2288-12181

24. Chenail RJ. Learning to Appraise the Quality of Qualitative Research Articles: A Contextualized Learning Object for Constructing Knowledge. Qualitative Report 2011;16(1): 236-248.

25. Franz CE, Barker JC, Kim K, et al. (2010). When help becomes hindrance: Mental health referral systems as barriers to care for primary care physicians treating patients with alzheimer's disease. Am J Geriatr Psychiatry. 2010;18(7):576-585. doi:https://doi.org/10.1097/JGP. Ob013e318la76df7

26. Petek D, Gajsek T, Petek Ster M. Work-family balance by women GP specialist trainees in Slovenia: A qualitative study. BMC Med Educ 2016;16(31):1-10. doi:https://doi.org/10.1186/s12909-016-0551-2
27. Hasbrouck MA, Waddimba AC. The work-related stressors and coping strategies of group-employed rural health care practitioners: A qualitative study. Am J Ind Med. 2017;60(10):867-878. doi:https://doi.org/10. 1002 /ajim. 22753

28. Beng TS, Chin LE, Guan NC, et al. The Experiences of Stress of Palliative Care Providers in Malaysia: A Thematic Analysis. Am J Hosp Palliat Med. 2015;32(1):15-28. doi:https://doi.org/10.1177/1049909113503395

29. Ciçekliołlu M, Öcek ZA, Turk M, et al. The influence of a marketoriented primary care reform on family physicians' working conditions: A qualitative study in Turkey. Eur J Gen Pract. 2015;21(2):97-102. doi:https://doi.org/10.3109/13814788.2014.966075

30. Flowerdew L, Brown R, Russ S, et al. Teams under pressure in the emergency department: An interview study. Emerg Med J. 2012;29(12):e2. doi:https://doi.org/10.1136/emermed-2011-200084

31. Iversen L, Farmer JC, Hannaford PC. Workload pressures in rural general practice: a qualitative investigation. Scand $J$ Prim Heal Care. 2002;20(3): 139-144.

32. McGowan Y, Humphries N, Burke H, et al. Through doctors' eyes: A qualitative study of hospital doctor perspectives on their working conditions. $\mathrm{Br} J$ Health Psychol. 2013;18(4):874-891. doi:https://doi. org/10.1111/bjhp. 12037

33. Picard J, Catu-Pinault A, Boujut E, et al. Burnout, empathy and their relationships: A qualitative study with residents in General Medicine. Psychol Heal and Med. 2016;21(3):354-361. doi:https://doi.org/10. 1080/13548506.2015.1054407

34. Turk M, Davas A. Tanik FA, et al. Organizational stressors, work-family interface and the role of gender in the hospital: Experiences from Turkey. Br J Health Psychol. 2014;19(2):442-458. doi:https://doi.org/10.1111/ bjhp. 12041

35. Post DM, Weddington WH. Stress and coping of the African-American physician. J Natl Med Assoc. 2000;92(2):70-75.

36. Spinelli WM, Fernstrom KM, Britt $\mathbf{H}$, et al. Seeing the patient is the joy: A focus group analysis of burnout in outpatient providers. Fam Med 2016;48(4):273-278. doi:https://doi.org/10.1007/s40596-017-0849-3

37. Schneider S, Kingsolver K, Rosdahl J. Physician coaching to enhance well-being: A qualitative analysis of a pilot intervention. Explor J Sci Heal. 2014;10(6):372-379. doi:https://doi.org/10.1016/j.explore.2014.08.007

38. Agana DF, Porter M, Hatch R, et al. Job satisfaction among academic family physicians. Fam Med. 2017 ; 49(8) :622-625.

39. Kjeldmand D, Holmström I. Balint groups as a means to increase job satisfaction and prevent burnout among general practitioners. Ann Fam Med. 2008;6(2):138-145. doi:https://doi.org/10.1370/afm.813

40. Miyasaki JM, Rheaume C, Gulya L, et al. Qualitative study of burnout, career satisfaction, and well-being among US neorologists in 2016. Neurology. 2017;89:1730-1738. doi:https://doi.org/10.1212/WNL. 0000000000004526

41. Orri M, Revah-Lévy A, Farges O. Surgeons' emotional experience of their everyday practice - A qualitative study. PLOS One, 2015;10(11):1-15. doi:https://doi.org/10.1371/journal.pone.0143763

42. Sturman $\mathbf{N}$, $\operatorname{Tan} \mathbf{Z}$, Turner J. "a steep learning curve": Junior doctor perspectives on the transition from medical student to the health-care workplace. BMC Med Educ. 2017;17(1):1-7. doi:https://doi.org/10. 1186/s12909-017-0931-2

43. Loukas A, Zucker RA, Fitzgerald HE, et al. Developmental trajectories of disruptive behavior problems among sons of alcoholics: effects of parent psychopathology, family conflict, and child undercontrol. J Abnorm Psychol. 2003;112(1):119-131. doi:https://doi.org/10.1037/0021843X.112.1.119

44. Verdonk P, Räntzsch V, De Vries $\mathbf{R}$, et al. Show what you know and dea with stress yourself: A qualitative interview study of medical interns' perceptions of stress and gender. BMC Med Educ. 2014;14(96). doi:https://doi.org/10.1186/1472-6920-14-96

45. Wainwright E, Fox F, Breffni T, et al. Coming back from the edge: A qualitative study of a professional support unit for junior doctors. BMC Med Educ. 2017;17(142). doi:https://doi.org/10.1186/s12909-0170978-0

46. Riley R, Spiers J, Buszewicz M, et al. What are the sources of stress and distress for general practitioners working in England? A qualitative study. BMJ Open. 2018;8(1):1-7. doi:https://doi.org/10.1136/bmjopen-2017017361

47. Granek L, Bartels U, Scheinemann K, et al. Grief Reactions and Impact of Patient Death on Pediatric Oncologists. Pediatr Blood Cancer. 2015;62(1):134-142. doi: https://doi.org/10.1002/pbc.25228

48. Menezes MA, Hodgson JM, Sahhar M, et al. "Taking Its Toll": The Challenges of Working in Fetal Medicine. Birth. 2013;40(1),52-60. doi:https://doi.org/10.1111/birt.12029 
49. Dzeng E, Colaianni A, Roland M, et al. Moral Distress Amongst American Physician Trainees Regarding Futile Treatments at the End of Life: A Qualitative Study. J Gen Intern Med. 2016;31(1):93-99. doi:https://doi.org/10.1007/s11606-015-3505-1

50. Zambrano SC, Chur-Hansen A, Crawford GB. The experiences, coping mechanisms, and impact of death and dying on palliative medicine specialists. Palliative and Supportive Care. 2014;12(4):309-316. doi:https://doi.org/10.1017/S1478951513000138

51. Gwala-Ngozo J, Taylor M, Aldous C. Understanding the experiences of doctors who undertake elective surgery on HIV/AIDS patients in an area of high incidence in South Africa. African J AIDS Res. 2010;9(1),11-16. doi:https://doi.org/10.2989/16085906.2010.484536

52. Fitzgerald $\mathbf{K}$, Yates $\mathbf{P}$, Benger $\mathbf{J}$, et al. The psychological health and wellbeing of emergency medicine consultants in the UK. Emerg Med J. 2017;34(7):430-435. doi:https://doi.org/10.1136/emermed-2015205246

53. Verhoef LM, Weenink JW, Winters $\mathbf{S}$, et al. The disciplined healthcare professional: a qualitative interview study on the impact of the disciplinary process and imposed measures in the Netherlands. BMJ Open. 2015;5(11). doi:https://doi.org/10.1136/bmjopen-2015-009275

54. Cheshire A, Ridge $\mathbf{D}$, Hughes $\mathbf{J}$, et al. Influences on GP coping and resilience: A qualitative study in primary care. $\mathrm{Br} J$ Gen Pract. 2017;67(659):428-436. doi:https://doi.org/10.3399/bjgp17X690893

55. Lindfors S, Boman J, Alexanderson K. Strategies used to handle stress by academic physicians at a university hospital. Work. 2012;43(2):183193. doi:https://doi.org/10.3233/WOR-2012-1364

56. Swetz KM, Harrington SE, Matsuyama RK, et al. Strategies for Avoiding Burnout in Hospice and Palliative Medicine: Peer Advice for Physicians on Achieving Longevity and Fulfillment. J Palliat Med. 2009;12(9):773-777. doi:https://doi.org/10.1089/jpm.2009.0050
57. Woolhouse S, Brown JB, Thind A. "Building through the Grief": Vicarious Trauma in a Group of Inner-City Family Physicians. $J$ Am Board Fam Med, 2012;25(6):840-846. doi:https://doi.org/10.3122/ jabfm.2012.06.120066

58. Zwack J, Schweitzer J. If every fifth physician is affected by burnout, what about the other four? resilience strategies of experienced physicians. Acad Med. 2013;88(3):382-389. doi:https://doi.org/10.1097/ ACM.0b013e318281696b

59. Bruchon-Schweitzer M, Boujut E. (2014). Psychologie de la Santé Concepts, Méthodes et modèles. Paris: Dunod ;2014, 542 p.

60. Southwick FS, Southwick SM. The Loss of a Sense of Control as a Major Contributor to Physician Burnout: A Neuropsychiatric Pathway to Prevention and Recovery. JAMA Psychiatry. 2018;75(7):665-666. doi:https://doi.org/10.1001/jamapsychiatry.2018.0566

61. Furnham A. (2012). The psychology of behaviour at work: The individual in the organization. London:Psychology Press; 1997,722p.

62. Bianchi R, Schonfeld IS, Laurent E. Burnout-depression overlap: a review. Clin Psychol Rev. 2015;36:28-41. doi: https://doi.org/10.1016/j. cpr.2015.T01.004

63. Leiter MP, Durup J. The discriminant validity of burnout and depression: a confirmatory factor analytic study. Anxiety Stress Coping. 1994;7:357-373. doi:https://doi.org/10.1080/10615809408249357

64. Moher D, Liberati A, Tetzlaff J, Altman DG, The PRISMA Group (2009). Preferred Reporting Items for Systematic Reviews and Meta-Analyses: The PRISMA Statement. PLoS Med 6 (6): e1000097. doi:https://doi.org/ 10.1371 /journal.pmed 10000

Publisher's Note Springer Nature remains neutral with regard to jurisdictional claims in published maps and institutional affiliations. 